\title{
Dynamics of change in the peri-urban landscape of Huerta de Valencia: the case of La Punta (Valencia)
}

\author{
R. Temes \& A. Moya \\ Department of Urban Design and Regional Planning, \\ Polytechnic University of Valencia, Spain
}

\begin{abstract}
This paper is a partial result of a wider research project that attempts to assess the changes in the urban and peri-urban fabric soils of the municipality of Valencia from 1944 to 2004 . The research presented focuses on the analysis of the nature of the changes and the dynamics of these over time in the area of $L a$ Punta, a town administrated by the city of Valencia (Spain) and located in the district of Quatre Carreres. The methodology is based on the analysis and measurement of changes in land structure, in the land use, in the occupation of building and in the forested areas presented in the traditional structure of nonurban roads. The key to measure such changes have been the use of the Cadaster of 1929-1944; 1972; 1989; orthophoto collections from the Valencian Regional Library and evolution of mapping from the SIOSE. The most outstanding results refer to the surprising resilience of some elements of the structure of the Huerta de Valencia and the discovery and identification of "landscapes" (plural) result of the different dynamics of change.
\end{abstract}

Keywords: urban transformations, resilience, GIS, Valencian community, Huerta de Valencia.

\section{Introduction}

Probably the Huerta of Valencia is one of the most rich and complex historical landscapes of the Valencian region due to its spatial morphology as well as by its architecture density, spaces and footprints that have been accumulated during centuries until today. This is due, most of it, because of its situation next to the biggest city of the old Valencian Kingdom and capital of the Sharq al-Andalus 
during the Muslim period which has produced a long and intense relationship between the urban and rural world that have been absolutely influenced by its long history [1]. A history that starts on the VIII century with the Muslim's peasants who designed and constructed the first hydric systems, found the first towns - the andalusi farmsteads - where they settled and constructed the first roads to connects the new towns with the main city. Time after, the feudal conquer of the XIII century brought a new model of social coexistence and power that produced a deep reconstruction of the landscape of the Huerta. It would be on the XIX century when, following the Bourgeois Revolution, different social and economic transformations take place that ended up modifying the agriculture landscape and beginning a new period of its history that lasted until our days, with a total rupture of the landscape by wide highways and roads and the progressive disappearance of the Huerta due to the actual urbanization and industrialization process. All these changes are perfectly explained and argued on the studies of Guinot [1,3] and Guinot and Castell [2].

Therefore, we must say that there have never been a Huerta speaking from a single entity but a different number of Huertas, a reflection of the society that managed, grew and transformed every part of it. Geographically, the historical Huerta of Valencia is formed by eight organized hydric systems: seven of them are part of the "Tribunal de las Aguas de Valencia" (canals of Rovella, Favara, Mislata-Xirivella, Quart-Benageber-Faitanar, Tormos, Rascanya and Mestalla) and the Royal Canal of Montcada. Also, on the limits of its historical hydric perimeter, there have been for centuries, and at least during the middle Ages, other small communities and institutions such as the "Comú de Monperot", the "Comú de Rafalterras" or the delegation of "Francs i Marjals" of the Valencia City Council, which was created on the XIV century together with small and abundant number of irrigation wells on the area of the Northern Huerta as well as on the South. All of them situated on the limits of the irrigation organized by communes and the areas of marshes.

\subsection{General objectives and structure of the work}

In this study the objective is to do an evaluation and analysis of the transformations that have been produced from 1944 to 2014 on a delimitated area of the historical Huerta of Valencia. More specifically, we will analyze the evolution of the last 70 years of an area known as "La Punta", integrated on the medieval irrigation system as a prolongation of the canal of Rovella [4]. "La Punta d'en Silvestre" was situated on the eastern limit of the medieval "Franc i Marjals", spaces dedicated to feed cattle and where, during the first part of the XIV century, were done sanitation operations changing the path of the left water from the irrigation system of Favara and Rovella towards the Guadalaviar (nowadays the river Turia). On this area, the abuses on the agriculture space of the Huerta have been intense and constant since the 1940s acquiring some important increment at the beginning of XXI century (the interval from 2004 to 2014 was the largest road network increased (13.25\%) and decreased the anthropic not use $(-12.21 \%)$. Its actual situation, confined between the South Boulevard of the city, the V-15 and the V-30, and its closeness to areas of last 
urban expansion and development such as the "Ciutat de les Arts i de les Ciencies", the partial development plan of "Les Moreres" and the ZAL area, creates a complicated situation for the agriculture space. Besides all these, time have demonstrated the capacity of resiliency of this space that invites to believe on its preservation despite the abuses that has had to face.

\subsection{Method of cartographic coordination}

The methodology used to do this study has been one of comparative analysis of cartographies managed by a Geographical Information System (GIS) and already used on other studies and reports done by the authors [5]. The primary sources for the reconstruction of the agriculture divisions of the land during the periods 1944, 1972, 1989, 2004 and 2014 have been the historical cartography base of the Cadaster. The Cadaster source has been the only one that, systematically and during the last 70 years, has done a precise and accurate description of each one of the urban and rural pots of the city. This information is, therefore, one of the most complete and trusty sources of information when facing a systematic analysis of a wide area. But, to be able to do this restitution, fist was needed the collection and digitalization of the cadaster collections used. These are divided on 4 groups, depending to a spatial reconstruction and two different regulation situations on paper and the last series digitally collected.

Despite the quality with which the Cadaster Service has been reconstructing its plot maps along its lifetime, it is inevitable that after trying to overlay the information of different periods of time, some little deformations occur due to the accumulation of different type of errors. The immediate strategy of establishing a comparison of a same section of an area on different periods of time usually faces important problems that reduce the quality of the final results. To solve it, we have followed a specific strategy overcoming two of the main problems of the cartography.

\subsubsection{The vertical an inverse coordination of the cartography}

To be able to do a correct comparison of the different periods, we have done, on the first place, a chronological inverse reconstruction of the mapping to guarantee the correct coordination of the cartography. This means start from the 2014 cartography and going back to the one done in 1944. We had the digital reconstruction of the plotting of Valencia of 2014 facilitated by the Web Assistance of the Spanish Cadaster [6]. With this vectorised plotting, and previous geo-position and digitalization of 1989, 1972, and 1944 cartographies, each period was vectorised. To do so, a process of, as we call, cartography coordination was done which is just a verification of relations between the cartographies of different periods, taking as support points the existing constructions or invariable points that assure the comparison of the period sequence studied. The coordination of the cartographies is not a simple process of drawing with a more or less precision of the different maps regarding different periods of a same territory, as can be understood. It is a vertical reconstruction of a cartography series that searches for buildings appearing on the different periods of time of the studied sequence. 


\subsubsection{The inevitable deformation of the cartography}

As we have already commented, the cartographic work of different periods of time usually brings different levels of quality that difficult the comparison of the maps. These distortions can hardly be solve by an automatize process. By doing so we are in risk of eliminating façades linings, building peculiarities or widening of streets that show variations during the study period. This is the reason of the costly and delicately process that must be done for the reconstruction of a coordinated cartography, usually accompany with a continuous consultation of complementary information to be able to understand the real situation. This process of identification is not absent of errors that must be taken into consideration to evaluate the level of exactitude of the base of the study for the analysis.

\subsubsection{Addition of complementary data}

It has been added to the restitution the height of each of the constructions, allowing a calculation of the total available construction area for each one of the periods. Due to the lack of information regarding qualitative data, we have used the geometrical data of the elements to obtain the areas and the available construction area. Three different types of areas have been classified: roads and facilities infrastructure, buildings and plots. The first two are what we called anthropic lands and the rest of the surfaces have been classified as portions: farm land or farming plots (one the constructions, roads and primary transportation network have been eliminated). But we are aware that the agricultural land is a creation of a human transformation, and therefore anthropic, we have preferred to keep a differentiation between the agricultural land and the rest.

\section{Development of the work}

The area of study has been limited so it covers which administratively is, inside the city of Valencia, the district of La Punta, where there is information about the 70 years analysis. The total area is about 592 ha which represent comparably around four times the Valencia's downtown area. The spatial coordination restitution of all the elements of the maps allows a time comparison of the cartographies, detecting the changes and transformations. The coincidence of the vertexes permits topological calculations of intersection and cutting, obtaining new geometries that limit the three types of land previously quoted.

For each one of the periods studied, a first calculation has been made regarding the surface occupied by connection and facilities infrastructures. The results are shown in Table 1.

The constructed areas have been calculated using the same procedure, doing the subtraction of plots by using the restitution of the building as base layer. On the reconstruction process the building' heights have been consulted which, including the surface area, allow us to calculate the final available construction area for each period. The result is shown in Table 2 . 
Table 1: Road network and equipment (surface).

\begin{tabular}{ccc}
\hline Year & Surface (sq. $\mathbf{~ m})$ & $\mathbf{\%}$ \\
\hline 1944 & 439,958 & 8.43 \\
1972 & 857,508 & 16.43 \\
1989 & $1,114,957$ & 21.36 \\
2004 & $1,544,340$ & 29.59 \\
2014 & $2,235,652$ & 42.84 \\
\hline
\end{tabular}

Table 2: Edification and potential development.

\begin{tabular}{cccc}
\hline Year & Road net. (sq. $\mathbf{m})$ & $\mathbf{\%}$ & Potential development (sq. m) \\
\hline 1944 & $213,014.09$ & 4.08 & $299,922.57$ \\
1972 & $257,738.57$ & 4.94 & $354,838.70$ \\
1989 & $358,964.19$ & 6.88 & $478,277.69$ \\
2004 & $409,988.67$ & 7.86 & $632,731.59$ \\
2014 & $355,843.67$ & 6.82 & $491,155.50$ \\
\hline
\end{tabular}

Finally, we calculate the existing agriculture plotting on each of the periods, as a result of subtracting the area occupied by constructions from the agricultural surface. This land is equal to the traditional production area of the Valencia's Huerta on the area of La Punta district. The result can be seen in Table 3.

Table 3: Portions.

\begin{tabular}{ccc}
\hline Year & Portions (sq. m) & \% \\
\hline 1944 & $4,566,154.27$ & 87.49 \\
1972 & $4,119,940.41$ & 78.94 \\
1989 & $3,745,96478$ & 71.78 \\
2004 & $3,264,682.83$ & 62.55 \\
2014 & $2,627,297.20$ & 50.34 \\
\hline
\end{tabular}

We can see how on each period of time a remarkable increase of land area dedicated to roadways and connection infrastructure as well as to facilities have been occurring. This increase has been produced basically by reducing the portion of agricultural land. We can also see how the areas dedicated to constructions grow up, except on 2014 when a reduction on the constructions area and built areas occurs. This is a consequence of diverse factors. On the one hand, on the south and southeast areas of La Punta, a large extension of land is 
urbanized so it can shelter the Logistic Activities Area (ZAL in Spanish), although after 10 years from the demolition of the last "barraca" nothing has been built on it. On the other hand, a great increase can be seen on the area dedicated to the purifying plant but, as the previous example, no constructions have been done to add constructed area. On the next graphics we can see the evolution of land uses.

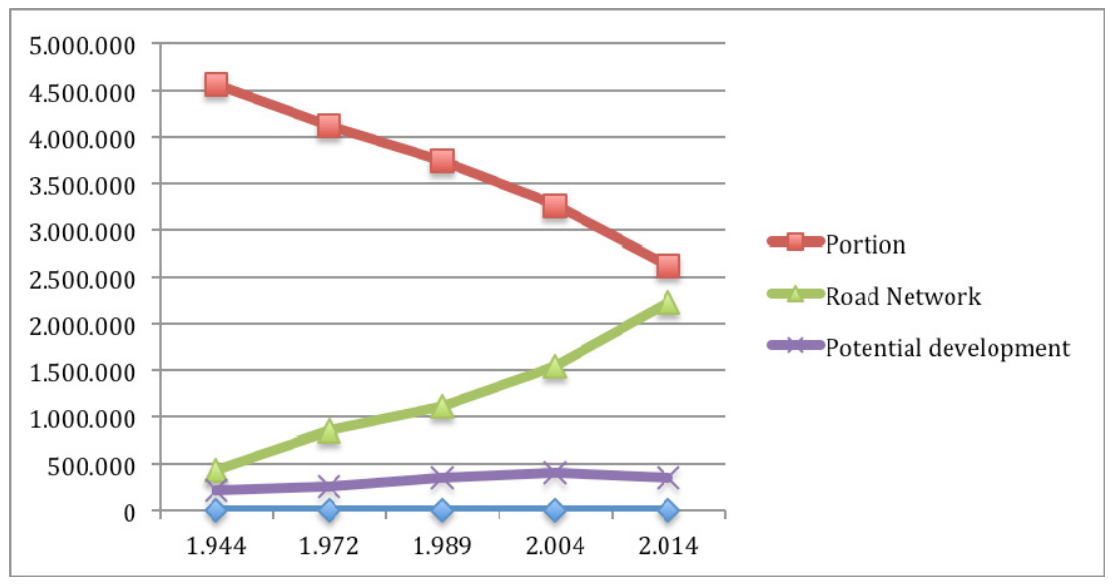

Figure 1: Land use graphic.

If we do a detailed study of the transformations by periods of time (Table 4) (Figure 2) we can make different comments of each case. On the one hand regarding the last period studied (2004-2014), the shortest one, where the major transformation intensity of the land has occurred. Its magnitude is $50 \%$ higher than the period before it (1989-2004) and doubled if we compare it to the period 1944-1972, even though this last period is identified as the era of urban development. If the transformation rate of approximately 60 ha every 10 years is maintained, in 40 years the 262.7 ha of agriculture land existing today would be consumed. Regarding available construction area, after what we have exposed on the previous parts of this report, a "fictitious effect" of stagnation is produced due to the no development of the ZAL area next to Valencia's harbor and the expansion of the purifying plant.

Table 4: Land use changes (sq. m).

\begin{tabular}{cccc}
\hline Period & Portions & Road network & Potential development \\
\hline 1944-1972 & $-446,213.86$ & $417,549.79$ & $44,724.48$ \\
$\mathbf{1 9 7 2}-\mathbf{1 9 8 9}$ & $-373,975.63$ & $257,449.16$ & $101,225.62$ \\
$\mathbf{1 9 8 9}-\mathbf{2 0 0 4}$ & $-481,281.95$ & $429,383.11$ & $51,024.48$ \\
$\mathbf{2 0 0 4}-\mathbf{2 0 1 4}$ & $-637,385.63$ & $691,312.58$ & $-54,145.00$ \\
\hline
\end{tabular}



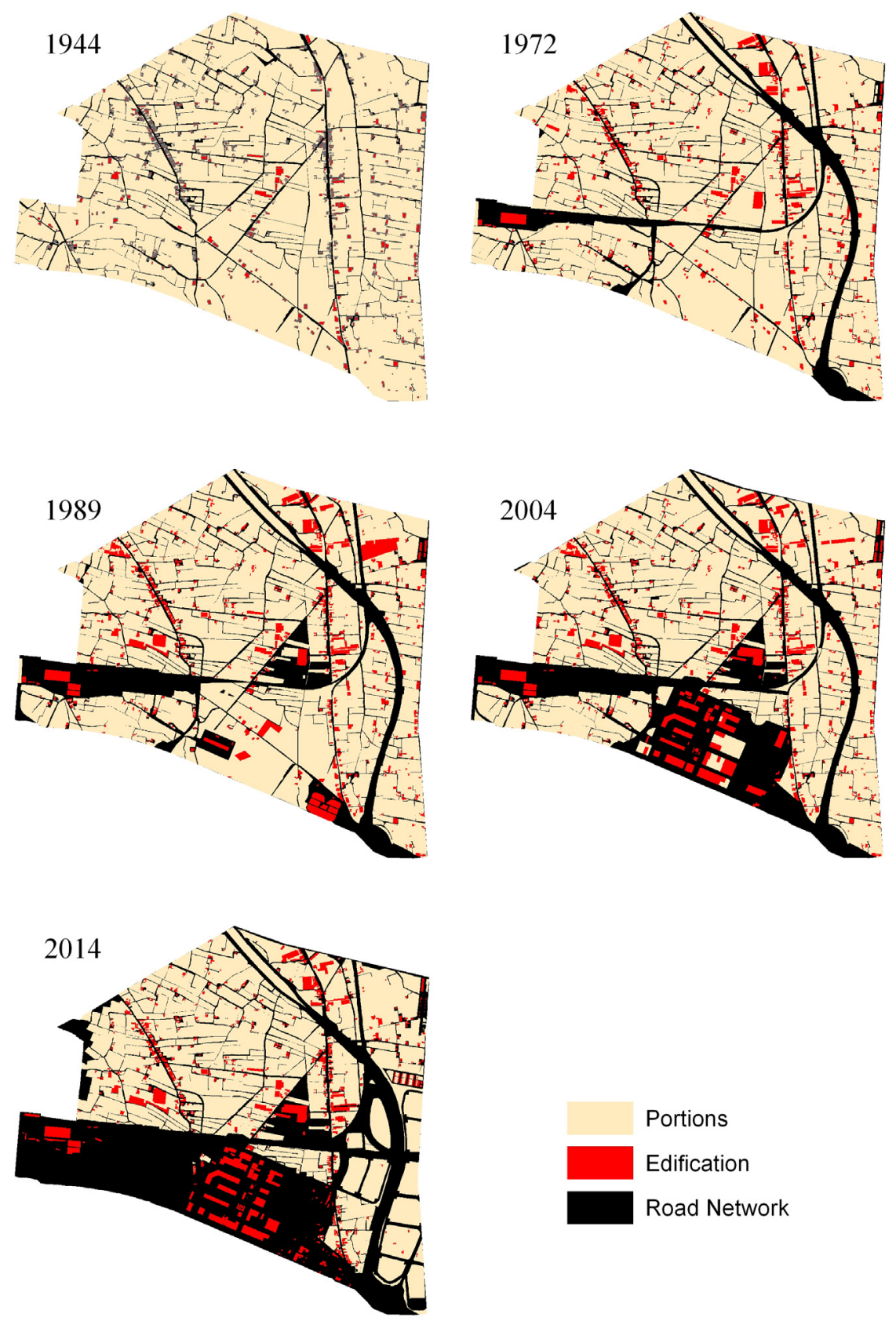

Portions

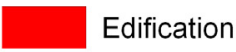

Road Network

Figure 2: Map evolution of "La Punta". 
On the other hand, if we focus on the period of lower transformation intensity of the last 70 years, we will choose the $1972-1989$ period. It is in this interval when the area receives new infrastructures, such as the railway and the south highway constructed during the 1970s. It is, therefore, a period of accessibility improvements on the district of La Punta, converting it into a future candidate for the construction of new facilities of the city, such as MercaValencia (logistic market place), the purifying plant or RENFE's railroad workshop. This effect can be seen on the high available construction area that it does characterize this period of time if we compare it with the previous and following ones.

Another effect that is interesting to be highlighted, as can be seen on Figure 2, is the process of quick anthropization that is occurring from the south of the studied area. The accumulation of large facilities or service spaces, as well as the artificial division created by large infrastructures, have drawn a completely different scenario from the original situation of the paths and networks of the Huerta that were developed for hundreds of years. The no attention and inconsiderateness towards the district of La Punta can be seen graphically through the comparison of the figures shown. The level of degradation is significant on the landscape of the Huerta, although the resiliency of this territory is remarkable because, despite all the abuses that have been committed, it maintains its irrigation system, the farming areas, traditional pathways, etc.

\section{Conclusions}

With a studied perspective of the last 70 years of the history of the Huerta of the district of La Punta, we can affirm that the major transformations developed on the area have occurred during the last 10 years. This has happened regarding magnitude as well as speed and aggressiveness, the most intense of it. If the rate of transformation done during the last decade is maintained, in less than 40 years this territory will disappear and the historical Huerta with it.

On the last 70 years the district of La Punta has suffered a loss of Huerta's surface close to 200 ha, a surface a little larger than the downtown area of Valencia. Despite the intensity of this transformation, La Punta has shown a high level of resiliency by keeping, overcoming adversities, its irrigation system, traditional paths, crops, etc.

The area of La Punta has progressively being transformed into a storing land of large infrastructures facilities of the city of Valencia: purifying plants, ZAL area, RENFE's railroad workshops. This collection of uses on the area shows the consideration as an empty plot of the area of Huerta, not taking into consideration any historical-heritage value existing on its structure and configuration.

It is necessary to apply and start to implement the Territorial Action Plan of the Valencian Huerta that, with an integral vision of the entire Valencian agriculture system, gives a use and a functionality to each part of the area. Not doing so, the weakness shown on the defense of some small portions of the 
independent Huerta will condemn it to its progressive disappearance or an inevitable degradation.

\section{References}

[1] Guinot, E., El paisaje de la Huerta de Valencia. Elementos de interpretación de su morfología espacial de origen medieval. Historia de la ciudad. V. Tradición y progreso, Colegio Oficial de Arquitectos de la Comunidad Valenciana; Universidad de Valencia; Universidad Politécnica de Valencia; Valencia Ayuntamiento, Valencia, pp. 116-129, 2008.

[2] Guinot, E., \& Castell, S., L'estudi del paisatge històric de les hortes mediterrànies: una proposta metodològica. Revista valenciana d'etnologia, n'3, pp. 100-124, 2008.

[3] Guinot, E., Una historia de la Huerta de Valencia. (Chapter 3). El patrimonio hidráulico del Bajo Turia: L'Horta de València. Vol. 9. Ed. J. Hermosilla, Dirección general de Patrimonio Cultural Valenciano, Valencia, pp. 60-102, 2007.

[4] Sanchis, C., Evolució histórica i canvi ambiental en l'espai hidrológic de l'Albufera de Valencia. PhD. Thesis, Departament de Geografia. Fac. de Geogr. Hist. Universitat de Valencia, p. 283, 1998.

[5] Temes, R., El Tapiz de Penélope. Transformaciones residenciales sobre tejidos sin valor patrimonial. PhD. Thesis, Departamento de Urbanismo. ETS de Arquitectura. UPV, Valencia, p. 778, 2007.

[6] Sede Electrónica del Catastro de España, www.sedecatastro.gob.es. 